\title{
Optimizing Hemodynamics with Transcatheter Arterial Embolization in Adrenal Pheochromocytoma Rupture
}

\author{
Naoki Edo ${ }^{1}$, Takahiro Yamamoto ${ }^{2}$, Satoshi Takahashi ${ }^{1}$, Yamato Mashimo ${ }^{1}$, Koji Morita ${ }^{1}$, \\ Koji Saito ${ }^{3}$, Hiroshi Kondo ${ }^{2}$, Yuko Sasajima ${ }^{3}$, Fukuo Kondo ${ }^{3}$, Hiroko Okinaga ${ }^{1}$, \\ Kazuhisa Tsukamoto ${ }^{1}$ and Toshio Ishikawa ${ }^{1}$
}

\begin{abstract}
:
Pheochromocytoma rupture is rare, and emergent adrenalectomy is associated with a high mortality. We herein report a patient with pheochromocytoma rupture who was stabilized by transcatheter arterial embolization (TAE) and subsequently underwent elective surgery. A 45-year-old man presented with the sudden onset of left lateral abdominal pain, headache, chest discomfort, high blood pressure, and adrenal hemorrhaging on enhanced abdominal computed tomography. TAE was performed under a provisional diagnosis of pheochromocytoma rupture. Following oral doxazosin, he underwent elective left adrenalectomy four and a half months after TAE. Stabilizing the hemodynamic status by TAE before adrenalectomy is a viable option for treating pheochromocytoma rupture.
\end{abstract}

Key words: pheochromocytoma, transarterial chemoembolization, rupture, hemorrhaging

(Intern Med 57: 1873-1878, 2018)

(DOI: 10.2169/internalmedicine.9907-17)

\section{Introduction}

Rupture or hemorrhaging is a rare complication of adrenal tumors. Only a few dozen cases of adrenal hemorrhaging have been reported in patients with pheochromocytoma. Emergent adrenalectomy in such cases is known to be associated with a high mortality.

We herein report a patient with pheochromocytoma rupture who was stabilized by transcatheter arterial embolization (TAE) before undergoing elective surgery.

\section{Case Report}

A 45-year-old man with a history of sleep apnea, nonischemic chronic heart failure, diabetes, and dyslipidemia presented to an emergency hospital with the sudden onset of left lateral abdominal pain, headache, and chest discomfort. High blood pressure $(181 / 142 \mathrm{mmHg})$ and adrenal hemorrhaging on enhanced abdominal computed tomography (CT) were observed (Fig. 1), and he was transferred to our hospital. A physical examination upon admission was unremarkable except for a blood pressure of $142 / 102 \mathrm{mmHg}$ (treated with $8 \mathrm{mg} / \mathrm{h}$ of nicardipine) and a heart rate of 107 beatsper-minute. The laboratory findings including hormonal data are shown in Table 1. Enhanced abdominal CT performed at the previous hospital showed left intratumoral hemorrhaging with a $6.5-\mathrm{cm}$ adrenal mass. Under a provisional diagnosis of pheochromocytoma rupture, TAE was performed in order to restore hemodynamic stability (Fig. 2). After embolization, his systolic blood pressure rose to $240 \mathrm{mmHg}$, and he was treated with intravenous phentolamine followed by oral doxazosin. In addition, severe constipation persisted for about one week.

Four and a half months after TAE, the patient underwent elective left adrenalectomy. During the period between TAE and surgery, the catecholamine level peaked 3 days postTAE before decreasing to around $0.085 \mu \mathrm{g} / \mathrm{mgCre}$ of urine metanephrine and $2.3 \mu \mathrm{g} / \mathrm{mgCre}$ of urine normetanephrine 1 month post-TAE and remained flat thereafter (Fig. 3). A his-

${ }^{1}$ Department of Internal Medicine, Teikyo University School of Medicine, Japan, ${ }^{2}$ Department of Radiology, Teikyo University School of Medicine, Japan and ${ }^{3}$ Department of Pathology, Teikyo University School of Medicine, Japan 
tological examination of the resected tumor confirmed the diagnosis of pheochromocytoma (Fig. 4) and showed several small arteries with irregular fibrous thickening and a collection of small vessels in the tumor (Fig. 5).

Since the surgery, he has been in good health, only taking $10 \mathrm{mg} /$ day of carvedilol for non-ischemic chronic heart failure. At 1 year postoperatively, his urinary metanephrine and normetanephrine were $0.063 \mu \mathrm{g} / \mathrm{mgCre}$ and $0.29 \mu \mathrm{g} / \mathrm{mgCre}$, respectively, and adrenal magnetic resonance imaging revealed no signs of local recurrence.

\section{Discussion}

Xarli et al. proposed a treatment algorithm for patients with adrenal hemorrhaging (1). However, treating pheochromocytoma rupture, which severely affects the hemodynam-

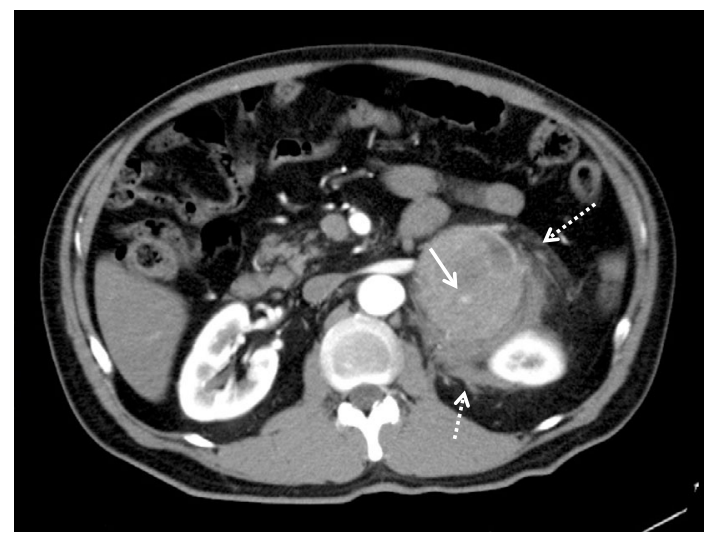

Figure 1. Enhanced abdominal computed tomography showing a $6.5-\mathrm{cm}$ left adrenal mass with cystic components and intratumoral extravasation of the contrast agent (solid arrow). Also, increased density of the peritumoral fat tissue was found (dotted arrows). ics, can be challenging. The clinical profiles of 74 cases reported in the literature are summarized in Table 2. The mortality rate can be as high as $40 \%$ in patients that subsequently undergo emergency adrenalectomy. However, there has only been 1 fatality (4\%) reported among the 7 patients who underwent delayed surgery with TAE (Table 3). The patient who died had pheochromocytoma rupture presenting as acute abdomen. Despite TAE, his blood pressure remained unstable, and emergency surgery was performed two hours later. However, he ultimately died six days after the surgery (2).

While TAE is considered an effective and minimally invasive option for arterial bleeding due to pheochromocytoma, emergency surgery might be unavoidable in some cases, as in the above-mentioned patient. Therefore, excluding the cases in which emergency surgery is necessary, TAE is a suitable option for the management of active bleeding from pheochromocytoma. In addition, even in the absence of active hemorrhaging, it may be beneficial to perform TAE to achieve hemodynamic stability in patients with fulminant cardiogenic shock (3) or to reduce perioperative blood loss from a giant hypervascular pheochromocytoma (4).

In the present case, the catecholamine level of the patient peaked at three days post-TAE, declined, and then remained flat from one month post-TAE. Severe but transient constipation, which was present for about one week after TAE, may reflect the post-TAE elevation in the levels of noradrenaline, the predominant catecholamine secreted by this patient's tumor, as noradrenaline plays an important role in causing constipation in pheochromocytoma (5). There have only been two reports evaluating the changes in the catecholamine levels around TAE. Bunuan et al. reported that, in their patient, the urinary vanillylmandelic acid level increased after TAE was performed for non-hemorrhaging pheochromocytoma (from $38.5 \mathrm{mg} / 24$ hours before TAE to

Table 1. Laboratory Data after Hospital Transfer and Administration of $8 \mathrm{mg} / \mathrm{h} \mathrm{of} \mathrm{Nicardipine.}$

\begin{tabular}{|c|c|c|c|c|c|c|c|}
\hline \multicolumn{2}{|c|}{ Blood Cell Count } & \multicolumn{2}{|c|}{ Biochemistry (continue) } & \multicolumn{2}{|l|}{ Endocrinology } & \multicolumn{2}{|c|}{ Blood Gas Analysis } \\
\hline WBC & $19,600 / \mu \mathrm{L}$ & $\mathrm{TP}$ & $8.5 \mathrm{~g} / \mathrm{dL}$ & ACTH & $97.8 \mathrm{pg} / \mathrm{mL}$ & $\mathrm{pH}$ & 7.482 \\
\hline $\mathrm{RBC}$ & $590 \times 10^{4} / \mu \mathrm{L}$ & $\mathrm{Alb}$ & $4.7 \mathrm{~g} / \mathrm{dL}$ & Cortisol & $55.7 \mu \mathrm{g} / \mathrm{dL}$ & $\mathrm{pO}_{2}$ & 119.0 Torr \\
\hline $\mathrm{Hb}$ & $19.0 \mathrm{~g} / \mathrm{dL}$ & Glu & $126 \mathrm{mg} / \mathrm{dL}$ & $\mathrm{TSH}$ & $3.290 \mu \mathrm{IU} / \mathrm{mL}$ & $\mathrm{pCO}_{2}$ & 31.6 Torr \\
\hline Hct & $54.0 \%$ & UA & $7.6 \mathrm{mg} / \mathrm{dL}$ & Free T4 & $1.26 \mathrm{ng} / \mathrm{dL}$ & $\mathrm{HCO}_{3}^{-}$ & $23.1 \mathrm{mEq} / \mathrm{L}$ \\
\hline $\mathrm{MCV}$ & $91.5 \mathrm{fL}$ & BUN & $15.8 \mathrm{mg} / \mathrm{dL}$ & Free $\mathrm{T} 3$ & $1.78 \mathrm{pg} / \mathrm{mL}$ & $\mathrm{BE}$ & $0.9 \mathrm{mEq} / \mathrm{L}$ \\
\hline $\mathrm{MCH}$ & $32.2 \mathrm{pg}$ & Cre & $0.92 \mathrm{mg} / \mathrm{dL}$ & PRA & $120 \mathrm{ng} / \mathrm{mL} / \mathrm{h}$ & & \\
\hline $\mathrm{MCHC}$ & $35.2 \%$ & $\mathrm{Na}$ & $137 \mathrm{mEq} / \mathrm{L}$ & Aldosterone & $506 \mathrm{pg} / \mathrm{mL}$ & & \\
\hline \multirow[t]{2}{*}{ Plt } & $29.2 \times 10^{4} / \mu \mathrm{L}$ & $\mathrm{K}$ & $4.7 \mathrm{mEq} / \mathrm{L}$ & Adrenaline & $0.06 \mathrm{ng} / \mathrm{mL}$ & & \\
\hline & & $\mathrm{Cl}$ & $99 \mathrm{mEq} / \mathrm{L}$ & Noradrenaline & $8.87 \mathrm{ng} / \mathrm{mL}$ & & \\
\hline \multicolumn{2}{|c|}{ Biochemistry } & $\mathrm{Ca}$ & $9.7 \mathrm{mg} / \mathrm{dL}$ & Dopamine & $0.07 \mathrm{ng} / \mathrm{mL}$ & & \\
\hline \multirow{6}{*}{$\begin{array}{l}\text { T-bil } \\
\text { D-bil } \\
\text { ALT } \\
\text { ALP } \\
\gamma \text { GTP }\end{array}$} & $1.34 \mathrm{mg} / \mathrm{dL}$ & $\mathrm{P}$ & $3.4 \mathrm{mg} / \mathrm{dL}$ & Calcitonin & $19 \mathrm{pg} / \mathrm{mL}$ & & \\
\hline & $1.34 \mathrm{llg} / \mathrm{dL}$ & T-Chol & $199 \mathrm{mg} / \mathrm{dL}$ & CEA & $3.3 \mathrm{ng} / \mathrm{mL}$ & & \\
\hline & $\begin{array}{l}0.18 \mathrm{mg} / \mathrm{dL} \\
113 \mathrm{JU} / \mathrm{L}\end{array}$ & $\mathrm{TG}$ & $117 \mathrm{mg} / \mathrm{dL}$ & DHEA-S & $1,332 \mathrm{ng} / \mathrm{mL}$ & & \\
\hline & $245 \mathrm{IU} / \mathrm{L}$ & HDL-C & $45.0 \mathrm{mg} / \mathrm{dL}$ & A1c(NGSP) & $6.6 \%$ & & \\
\hline & $24510 / \mathrm{L}$ & CRP & $0.44 \mathrm{mg} / \mathrm{dL}$ & $\mathrm{u}-\mathrm{MN}$ & $0.25 \mu \mathrm{g} / \mathrm{mgCre}$ & & \\
\hline & & & & u-NMN & $11.0 \mu \mathrm{g} / \mathrm{mgCre}$ & & \\
\hline
\end{tabular}

DHEA-S: dehydroepiandrosterone sulfate, u-MN: urinary metanephrine, u-NMN: urinary normetanephrine 


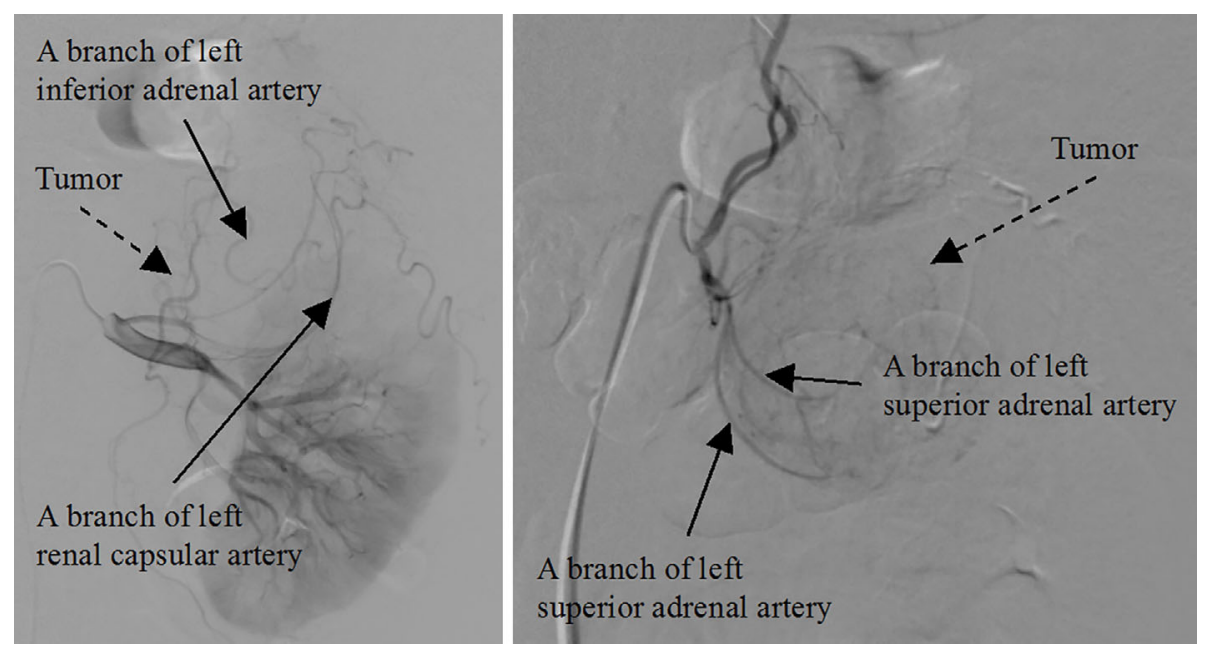

Figure 2. Transcatheter artery embolization (TAE). TAE of arteries (arrows) was performed.

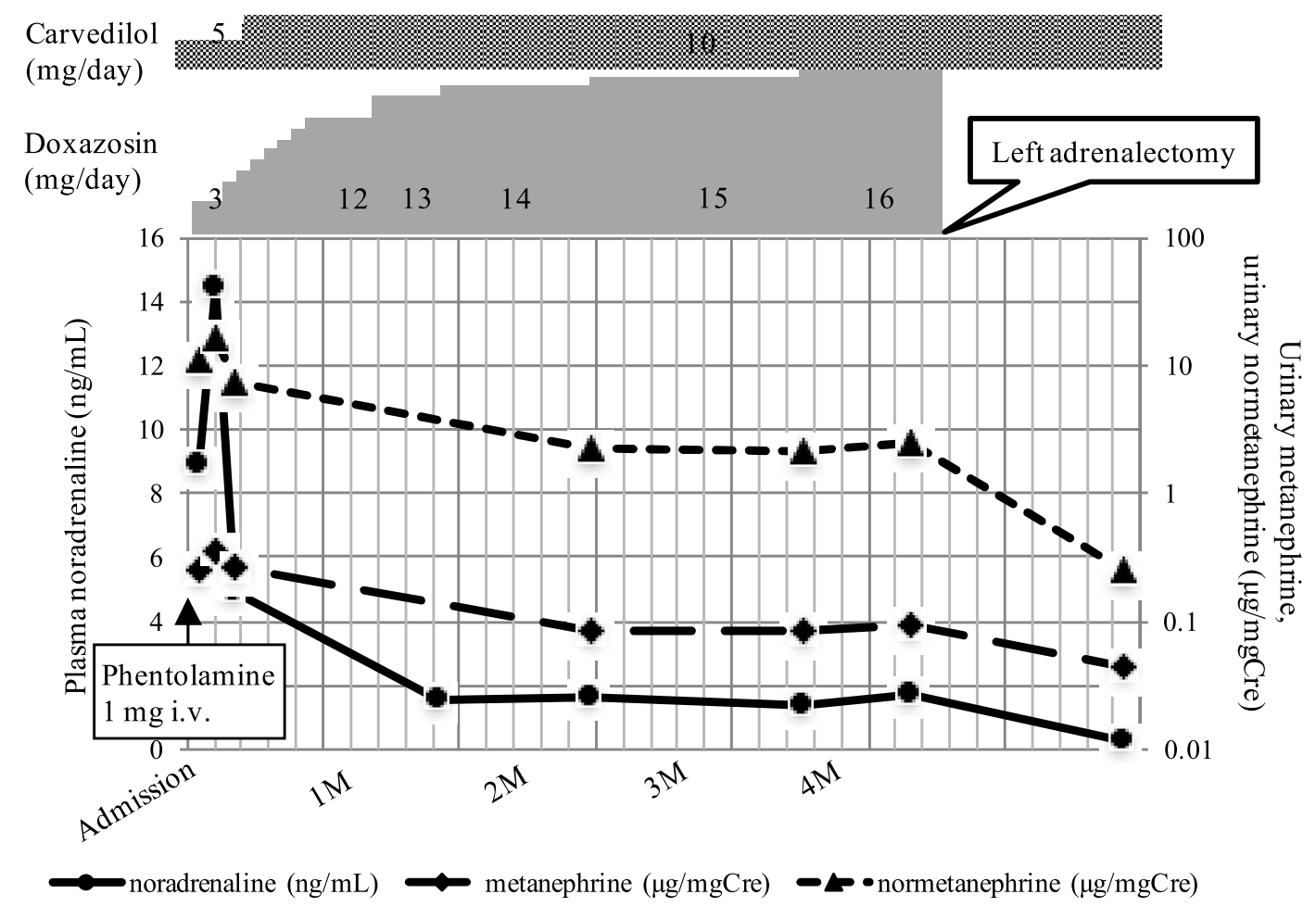

Figure 3. Clinical course and changes of catecholamine levels after TAE.

$>200 \mathrm{mg} / 24$ hours at 1 day after TAE). Their patient complained of nausea and epigastric pain a few hours after TAE (6). In contrast, Teranishi et al. reported that the plasma noradrenaline level decreased after TAE of a catecholamine-secreting Glomus jugulare tumor (7). Changes in the catecholamine levels and symptoms might be dependent on the histology of the tumor, the bioactivity of the secreted catecholamine, and the technique of TAE. The further accumulation of cases may help predict changes in the catecholamine levels and symptoms after TAE.

The exact mechanism underlying pheochromocytoma rupture is unknown. In the present case, a pathological evaluation of the resected left adrenal gland showed several small arteries with irregular fibrous thickening and a collection of small vessels in the tumor. The fibrous thickening of small arteries indicates heterogeneous arterial repair, which may suggest the influence of localized endothelial cell dysfunction and/or persistent mechanical stimulation (e.g. hypertension and/or mass effect). In addition, endothelial cell dysfunction and heterogeneous remodeling may be associated with microthrombogenesis as well (8). The collection of small vessels in the tumor may indicate angiogenesis and the formation of granulation tissue, which reflects the remodeling process following intratumoral hemorrhaging and necrosis. Further histological studies are needed to clarify the mechanism underlying pheochromocytoma rupture. 
(a)

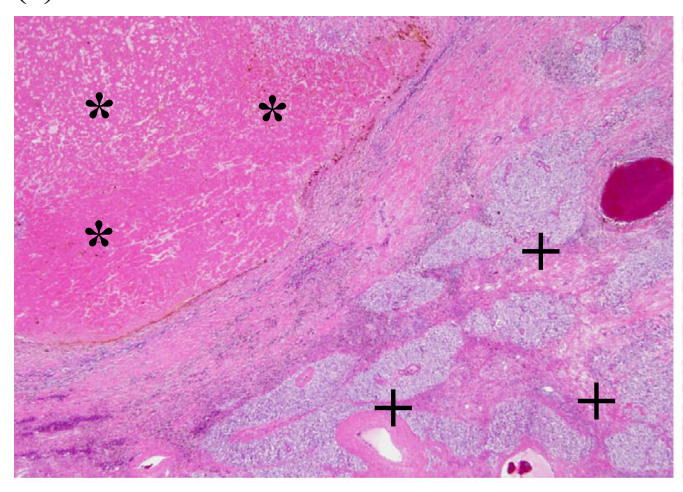

(b)

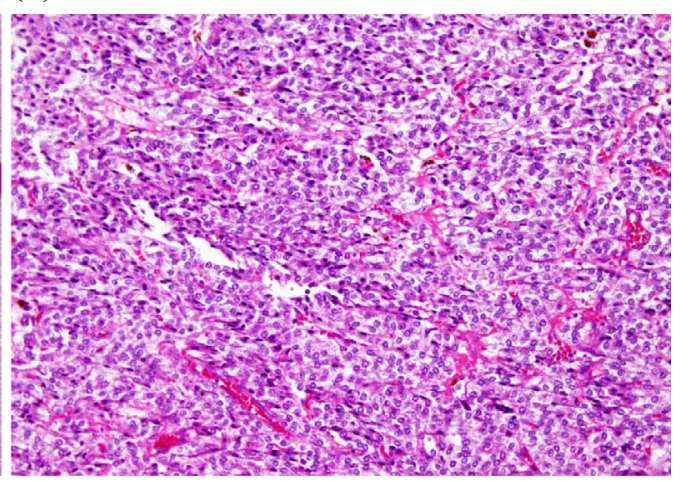

(c)

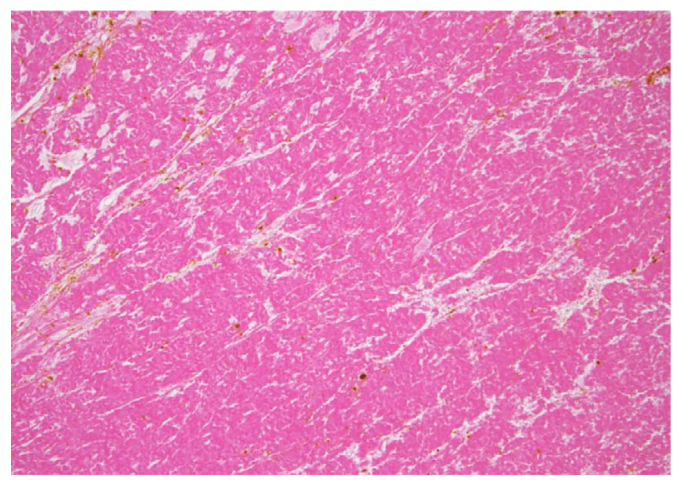

Figure 4. Histology of the resected tumor. (a) The tumor consists of viable $(+)$ and necrotic regions $(*)(\times 20)$. (b) Viable tumor cells a Zellballen architecture, which is a small compartmentalized nest of tumor cells, infiltrated by a fibrovascular stroma $(\times 200)$. (c) Ghost cells and vascular stroma are found in some areas of necrosis $(\times 100)$.

(a)

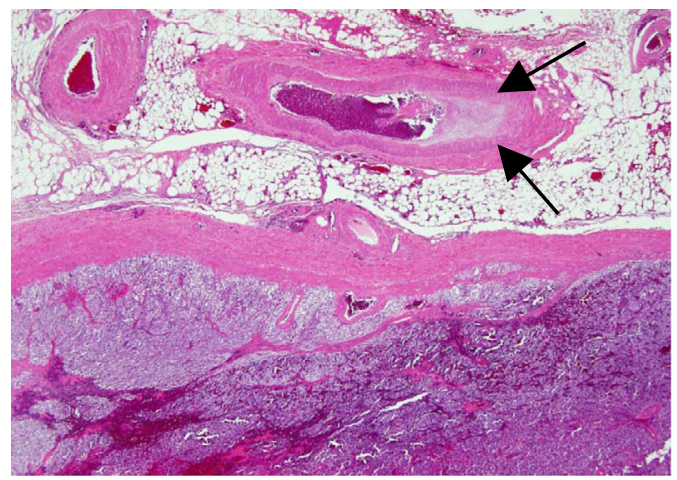

(c)

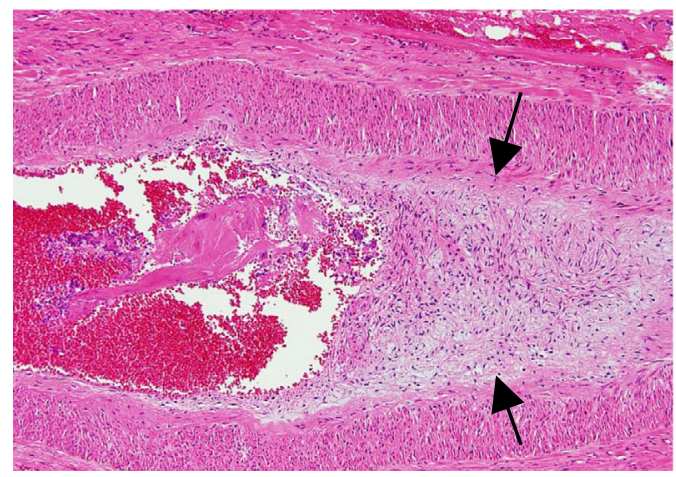

(b)

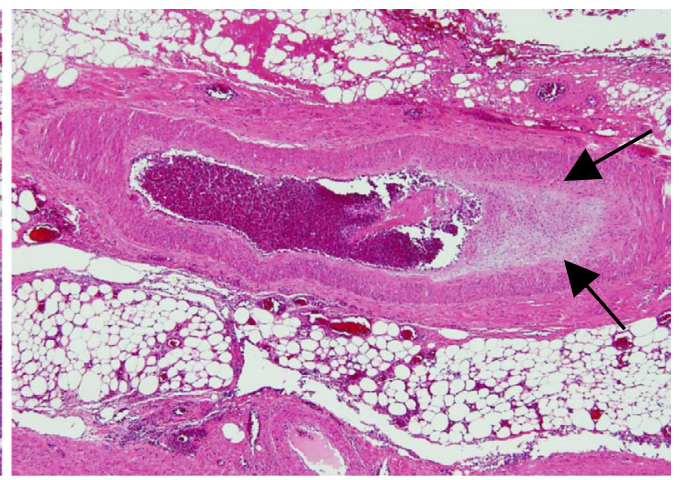

(d)

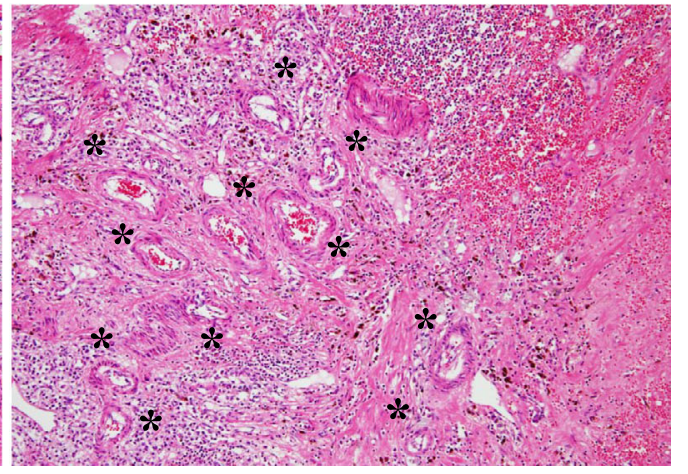

Figure 5. Histology of the resected tumor. There were several small arteries with irregular fibrous thickening $(\mathrm{a}: \times \mathbf{2 0}, \mathrm{b}: \times \mathbf{4 0}$, and $\mathrm{c}: \times 100)$, and a collection of small vessels $(*)$ in the tumor $(\mathrm{d}: \times 100)$. 
Table 2. Clinical Profiles of 74 Cases of Pheochromocytoma Rupture.

\begin{tabular}{|c|c|}
\hline Age & $15-84$ years. (average, 50.5 years) (our case, 45 years) \\
\hline Gender & Male $41(55 \%)$, Female $33(45 \%)$ \\
\hline Side & Right 39 (53\%), Left 33 (44\%), Bilateral $2(3 \%)$ \\
\hline Symptom & $\begin{array}{l}\text { Abdominal pain } 58(78 \%) \text {, Shock } 38(51 \%) \text {, Chest pain } 16(22 \%) \text {, } \\
\text { Lumbar pain } 13(18 \%)\end{array}$ \\
\hline Bleeding site & Retroperitoneal 41 (55\%), Intratumoral 18 (24\%), Intraperitoneal $15(21 \%)$ \\
\hline Treatment & $\begin{array}{l}\text { Emergency surgery } 35(47 \%) \text {, Elective surgery } 20(27 \%) \text {, } \\
\text { Conservative } 12(16 \%) \text {, Elective surgery after TAE } 7(10 \%)\end{array}$ \\
\hline Outcome & Survived $54(73 \%)$, Died $20(27 \%)$ \\
\hline Mortality Rate & $\begin{array}{l}\text { Emergency surgery or conservative treatment: } 40 \% \\
\text { Delayed surgery with or without TAE: } 4 \%\end{array}$ \\
\hline
\end{tabular}

Table 3. Details of Cases with Delayed Surgery after TAE.

\begin{tabular}{|c|c|c|c|c|c|}
\hline Reference & $\begin{array}{c}\text { Age } \\
\text { Gender }\end{array}$ & $\begin{array}{l}\text { Catecholamine levels } \\
\text { upon admission }\end{array}$ & $\begin{array}{c}\text { Side } \\
\text { (Bleeding site) }\end{array}$ & Interval & Note \\
\hline (9) & $68 \mathrm{~F}$ & $\begin{array}{l}\text { NA } 4.90 \mathrm{ng} / \mathrm{mL} \\
\text { DA } 61.0 \mathrm{ng} / \mathrm{mL} \\
\text { (on dopamine) }\end{array}$ & $\begin{array}{l}\text { Left } \\
(\mathrm{RP})\end{array}$ & 3 months & $\begin{array}{l}\text { Blood and urinary } \\
\text { catecholamine levels were } \\
\text { normal. }\end{array}$ \\
\hline (10) & $32 \mathrm{M}$ & $\begin{array}{c}\text { A: } 68.0 \mathrm{pg} / \mathrm{mL} \\
\text { NA: } 8,529.0 \mathrm{pg} / \mathrm{mL} \\
\text { u-MN: } 8.2 \mathrm{mg} / \text { day }\end{array}$ & $\begin{array}{l}\text { Right } \\
\text { (IT) }\end{array}$ & 21 days & $\begin{array}{l}\text { Bilateral adrenal } \\
\text { enlargement }\end{array}$ \\
\hline (11) & $67 \mathrm{M}$ & $\begin{array}{l}\text { u-MN: } 33,376 \mathrm{nmol} / \text { day } \\
\text { u-NMN: } 14,919 \mathrm{nmol} / \text { day }\end{array}$ & $\begin{array}{l}\text { Right } \\
(\mathrm{RP})\end{array}$ & 2 months & n.p. \\
\hline (12) & $42 \mathrm{M}$ & u-VMA: $31 \mathrm{mg} /$ day & $\begin{array}{l}\text { Right } \\
(\mathrm{RP}+\mathrm{IT})\end{array}$ & 1 month & n.p. \\
\hline (13) & $38 \mathrm{M}$ & $\begin{array}{l}\text { s-MN } 14.0 \mathrm{nmol} / \mathrm{L} \\
\text { s-NMN } 24.3 \mathrm{nmol} / \mathrm{L}\end{array}$ & $\begin{array}{l}\text { Left } \\
\text { (IP) }\end{array}$ & 4.5 months & $\begin{array}{l}\text { MEN 2A. Bilateral adrenal } \\
\text { enlargement. Damage } \\
\text { control surgery for } \\
\text { hemorrhage. }\end{array}$ \\
\hline (14) & $63 \mathrm{M}$ & $\begin{array}{l}\text { Not measured } \\
\text { (Pathological } \\
\text { diagnosis only) }\end{array}$ & $\begin{array}{l}\text { Left } \\
\text { (RP) }\end{array}$ & 1 month & $\begin{array}{l}\text { At preoperative evaluation, } \\
{ }^{131} \text { I-MIBG was positive, but } \\
\text { urinary catecholamine } \\
\text { levels were normal. }\end{array}$ \\
\hline (2) & $40 \mathrm{M}$ & $\begin{array}{c}\text { A: } 8.83 \mathrm{ng} / \mathrm{mL} \\
\text { NA: } 45.99 \mathrm{ng} / \mathrm{mL} \\
\text { DA: } 6.5 \mathrm{ng} / \mathrm{mL}\end{array}$ & $\begin{array}{l}\text { Left } \\
\text { (RP) }\end{array}$ & 2 hours & Dead six days after surgery. \\
\hline
\end{tabular}

A: adrenaline, DP: dopamine, F: female, IP: intraperitoneal, IT: intratumoral, M: male, MEN 2A: multiple endocrine neoplasia type 2A, ${ }^{131}$ I-MIBG: 131I-meta-iodobenzylguanidine, NA: noradrenaline, RP: retroperitoneal, u-MN: urinary metanephrine, u-NMN: urinary normetanephrine, u-VMA: urinary vanillylmandelic acid

In conclusion, stabilizing the hemodynamic status with TAE followed by adrenalectomy may be a suitable option for treating pheochromocytoma rupture. However, a careful evaluation is important, as there are some cases in which hemodynamic stabilization is difficult to achieve with TAE alone.

The authors state that they have no Conflict of Interest (COI).

\section{References}

1. Xarli VP, Steele AA, Davis PJ, Buescher ES, Rios CN, Garcia-Bunuel R. Adrenal hemorrhage in the adult. Medicine (Baltimore) 57: 211-221, 1978.

2. Mukai S, Sakimoto H, Kouchi M, et al. A case of a spontaneous rupture of adrenal pheochromocytoma that caused rapid and poor course. Nihon Fukubu Kyukyu Igakkai Zasshi (J Abdom Emerg Med) 33: 161-165, 2013 (in Japanease, Abstract in English).

3. Vagner H, Hey TM, Elle B, Jensen MK. Embolisation of pheochromocytoma to stabilise and wean a patient in cardiogenic shock from emergency extracorporeal life support. BMJ Case Rep 2015: pii: bcr2014206069, 2015.

4. Sormaz IC, Tunca F, Poyanlı A, Şenyürek YG. Preoperative adrenal artery embolization followed by surgical excision of giant hypervascular adrenal masses: report of three cases. Acta Chir Belg Apr 7: 1-7, 2017.

5. Thosani S, Ayala-Ramirez M, Román-González A, et al. Constipation: an overlooked, unmanaged symptom of patients with pheochromocytoma and sympathetic paraganglioma. Eur J Endocrinol 173: 377-387, 2015.

6. Bunuan HD, Alltree M, Merendino KA. Gel foam embolization of a functioning pheochromocytoma. Am J Surg 136: 395-398, 1978. 
7. Teranishi Y, Kohno M, Sora S, Sato H, Haruyama N. Perioperative management of catecholamine-secreting Glomus jugulare tumors. J Neurol Surg Rep 65: e170-e174, 2014.

8. Squizzato A, Gerdes VE, Ageno W, Buller HR. The coagulation system in endocrine disorders: a narrative review. Intern Emerg Med 2: 76-83, 2007.

9. Ito K, Nagata H, Miyahara M, Saito S, Murai M, Narimatsu Y. [Embolization for massive retroperitoneal hemorrhage from adrenal pheochromocytoma: a case report]. Hinyokika Kiyo (Acta Urol Jpn) 43: 571-575, 1997 (in Japanese, Abstract in English).

10. Park JH, Kang KP, Lee SJ, Kim CH, Park TS, Baek HS. A case of a ruptured pheochromocytoma with an intratumoral aneurysm managed by coil embolization. Endocr J 50: 653-656, 2003.

11. Pua U, Wong DE. Transarterial embolisation of spontaneous adrenal pheochromocytoma rupture using polyvinyl alcohol particles. Singapore Med J 49: e126-e130, 2008.
12. Habib M, Tarazi I, Batta M. Arterial embolization for ruptured adrenal pheochromocytoma. Curr Oncol 17: 65-70, 2010.

13. Hanna JS, Spencer PJ, Savopoulou C, Kwasnik E, Askari R. Spontaneous adrenal pheochromocytoma rupture complicated by intraperitoneal hemorrhage and shock. World J Emerg Surg 6: 27, 2011.

14. Kumar S, Nanjappa B, Kumar S, Prasad S, Pushkarna A, Singh SK. Adrenal artery pseudoaneurysm in pheochromocytoma presenting with catastrophic retroperitoneal haemorrhage. Can Urol Assoc J 7: E254-E256, 2013.

The Internal Medicine is an Open Access article distributed under the Creative Commons Attribution-NonCommercial-NoDerivatives 4.0 International License. To view the details of this license, please visit (https://creativecommons.org/licenses/ by-nc-nd/4.0/).

(C) 2018 The Japanese Society of Internal Medicine Intern Med 57: 1873-1878, 2018 